\title{
Sugar and abscisic acid signaling orthologs are activated at the onset of ripening in grape
}

\author{
Gregory A. Gambetta $\cdot$ Mark A. Matthews • \\ Tarana H. Shaghasi • Andrew J. McElrone • \\ Simone D. Castellarin
}

Received: 3 February 2010/ Accepted: 30 March 2010/Published online: 21 April 2010

(C) The Author(s) 2010. This article is published with open access at Springerlink.com

\begin{abstract}
The onset of ripening involves changes in sugar metabolism, softening, and color development. Most understanding of this process arises from work in climacteric fruits where the control of ripening is predominately by ethylene. However, many fruits such as grape are nonclimacteric, where the onset of ripening results from the integration of multiple hormone signals including sugars and abscisic acid (ABA). In this study, we identified ten orthologous gene families in Vitis vinifera containing components of sugar and ABA-signaling pathways elucidated in model systems, including PP2C protein phosphatases, and WRKY and homeobox transcription factors. Gene expression was characterized in control- and deficitirrigated, field-grown Cabernet Sauvignon. Sixty-seven orthologous genes were identified, and 38 of these were expressed in berries. Of the genes expressed in berries, $68 \%$ were differentially expressed across development and/ or in response to water deficit. Orthologs of several families were induced at the onset of ripening, and induced earlier and to higher levels in response to water deficit;
\end{abstract}

Electronic supplementary material The online version of this article (doi:10.1007/s00425-010-1165-2) contains supplementary material, which is available to authorized users.

G. A. Gambetta $(\bowtie) \cdot$ M. A. Matthews · T. H. Shaghasi

Department of Viticulture and Enology, University of California, 1 Shields Ave, Davis, CA 95616, USA

e-mail: gagambetta@ucdavis.edu

\section{A. J. McElrone}

USDA-ARS, Crops Pathology and Genetics Research Unit, University of California, 1 Shields Ave, Davis, CA 95616, USA

\section{S. D. Castellarin}

Dipartimento di Scienze Agrarie e Ambientali,

University of Udine, Via delle Scienze 208, 33100 Udine, Italy patterns of expression that correlate with sugar and $\mathrm{ABA}$ accumulation during ripening. Similar to field-grown berries, ripening phenomena were induced in immature berries when cultured with sucrose and ABA, as evidenced by changes in color, softening, and gene expression. Finally, exogenous sucrose and ABA regulated key orthologs in culture, similar to their regulation in the field. This study identifies novel candidates in the control of nonclimacteric fruit ripening and demonstrates that grape orthologs of key sugar and ABA-signaling components are regulated by sugar and ABA in fleshy fruit.

Keywords Vitis vinifera . Nonclimacteric fruit . Hormone action - Water deficit

\section{Introduction}

It is often asserted and then assumed that fundamental research from model systems, such as Arabidopsis, is valuable because this knowledge would be utilized later to elucidate practical aspects of plant function in species of agronomic importance. This has been successful in like organs and developmental processes. For example, a regulatory module involved in photoperiod control of flowering has been elucidated through extensive research in Arabidopsis (reviewed in Imaizumi and Kay 2006), and more recently this same mechanism has been shown to control flower time in Populus trichocarpa (Bohlenius et al. 2006). Unexpectedly, Bohlenius et al. (2006) revealed that the same regulatory module is involved in the control of bud dormancy. This illustrates that components of regulatory mechanisms can be conserved across disparate developmental processes that share commonalities; a dependence on daylength and action in the shoot apex in 
the case of flowering and bud dormancy. Less is known about the utility of extending knowledge to a class of organ not even present in a given model species.

The onset of ripening marks a transition in fruit development leading to changes in physiology involving sugar metabolism, softening, and color development. Most understanding of this process arises from work with climacteric fruits in which the control of ripening is predominately by ethylene. However, there are many fruits of economic importance that are nonclimacteric, such as grape, strawberry, and citrus, where the processes controlling the onset of ripening are still poorly understood. Study has traditionally focused on ethylene in climacteric fruits and on other hormones such as sugar and abscisic acid (ABA) in nonclimacteric fruits. However, there are numerous studies implicating ethylene in the ripening of nonclimacteric fruits (Chervin et al. 2004; Trainotti et al. 2005), and conversely, sugar and ABA in the ripening of climacteric fruits (Chernys and Zeevaart 2000; Leclercq et al. 2002; Lieberman et al. 1977; Telef et al. 2006). In addition, other hormones have been show to influence the ripening processes such as auxin (Davies et al. 1997; Trainotti et al. 2007) and brassinosteroids (Fu et al. 2008; Lisso et al. 2006; Symons et al. 2006). Fruit ripening in general involves the integration of multiple hormone signals. Climacteric and nonclimacteric fruits are not delimited by phylogeny and both exist even among closely related species (reviewed in Giovannoni 2004). This suggests that ripening in all fleshy fruit may have a common foundation.

Sugar and ABA function as signals in many aspects of plant development (reviewed in Gibson 2004; Rook et al. 2006) and there are numerous lines of evidence correlating increases in sugar and ABA with the onset of ripening in grape (Davies et al. 1997; Deluc et al. 2009; Mei et al. 2009; Wheeler et al. 2009). In field-grown berries, exogenous ABA increases anthocyanin accumulation (Peppi et al. 2006, 2008; Wheeler et al. 2009), and in our own work berries fail to synthesize anthocyanins when sugar import into the berry is disrupted via phloem girdling prior to the onset of ripening (unpublished data). Exogenous applications of both sugars and ABA increase anthocyanin accumulation in cell and tissue culture (Hiratsuka et al. 2001; Larronde et al. 1998; Matsushima et al. 1989; Pirie and Mullins 1976). Finally, water deficits also result in increases in anthocyanin accumulation (Castellarin et al. 2007a, b; Deluc et al. 2009; Matthews and Anderson 1988), and have been shown to increase ABA accumulation at the onset of ripening (Okamoto et al. 2004; Antolin et al. 2008; Deluc et al. 2009).

Many studies investigating the role of sugar and ABA in ripening have focused on color development. In viticulture, the onset of ripening is traditionally referred to as veraison and is defined by the initiation of color development. More contemporary genomic studies demonstrate that color can act as a proxy for developmental stage in that individual grape berries of like color have similar global gene expression patterns (Lund et al. 2008). A previous study in our laboratory found that water deficits advanced the onset of color development, but sugar and anthocyanin accumulation remained closely linked (Castellarin et al. 2007a). Furthermore, the induction of core flavonoid and anthocyanin-specific genes reflected this advancement as well (Suppl. Fig. 1). Therefore, in the current study, water deficit is used as a means to manipulate the timing of the onset of ripening in the field.

There are few examples of studies focused on identifying the molecular mechanisms responsible for sugar and ABA action in grape, although several recent studies have demonstrated roles for sugar and ABA in controlling sugar metabolism. ABA stimulates acid invertase activity (Pan et al. 2005), and expression of the grape hexose transporter $V v H T 1$ is regulated by both ABA and hexose (Cakir et al. 2003; Conde et al. 2006). Two other recent studies have focused on core sugar and ABA-signaling components. A calcium-dependent protein kinase is regulated by $\mathrm{ABA}$ during ripening (Yu et al. 2006), and a study in grape cell culture provides evidence that sugar induced increases in anthocyanin accumulation are dependent on calcium, calmodulin, and kinase activity (Vitrac et al. 2000).

In this study, we begin to examine the hypothesis that orthologous sugar and ABA-signaling components, characterized across such diverse processes as seed dormancy and stomatal control, function similarly in the control of the onset of ripening in fleshy fruit. This study employs a comprehensive approach in identifying novel sugar and ABA-signaling candidates in grape. Ten gene families, containing sugar and ABA-signaling components elucidated in model systems, were considered including; the putative sucrose sensor SUT2, core G-protein signaling components GPA1 and RGS1, hexokinases (Hxk), PP2C protein phosphatases, Snf1-related kinases (SnRK), and the sugar-related WRKY, and ABA-related homeodomain-leucine zipper, or homeobox (HB), ABRE-binding factor (ABF), and AP2 transcription factors (reviewed in Hirayama and Shinozaki 2007; Koch 2004; Leung and Giraudat 1998; Rolland et al. 2006; Rook et al. 2006). Their orthologous families in grape were identified, and the expression of individual genes were characterized in control- and deficit-irrigated, field-grown Cabernet Sauvignon. The onset of ripening was induced in cultured immature berries with sugar and ABA treatments. Finally, the effect of exogenous sugar and ABA on the expression of several key orthologs was investigated in berry culture. 


\section{Materials and methods}

Field experiment and physiological measurements

The field experiment was the same as presented in Castellarin et al. (2007a). In short, experiments were conducted during 2006 in a commercial vineyard of R.H. Phillips Winery (Esparto, CA, USA) using Vitis vinifera "Cabernet Sauvignon" clone 337 grafted onto rootstock 140R. Two irrigation treatments were established. Irrigation was applied to control (C) vines in order to maintain midday leaf water potential $\left(\Psi_{\text {leaf }}\right)$ between -0.9 and $-1.2 \mathrm{MPa}$. Irrigation was cut off to early deficit (ED) vines at fruit set until 77 days after anthesis (DAA); then vines were irrigated at the $\mathrm{C}$ rate till 133 DAA. Plant water status was monitored weekly by measuring midday leaf water potential according to Matthews et al. (1987). Each treatment was replicated four times in 0.5-ha plots dispersed over a 36-ha vineyard according to a randomized complete block design. Samples were collected randomly from ten vines located in the central row of the plots. Berries were sampled six times between 27 June (33 DAA) and 5 October (133 DAA), when the grapes were harvested. Twenty berries were collected from each plot for use in studies of gene expression. During the onset of ripening, samples of green and red berries were collected separately from the same clusters and analyzed separately.

\section{Bioinformatics and ortholog identification}

Amino acid sequences of each $\mathrm{ABA}$ and sugar signaling gene of interest were obtained from NCBI. These sequences were then BLASTed against the predicted grape proteome via the Genoscope Vitis BLAST server (http://www. genoscope.cns.fr/cgi-bin/blast_server/projet_ML/blast.pl) using a BLOSUM62 matrix. In cases with reasonable numbers $(<10)$ of predicted orthologs, all significant hits were recorded, and their corresponding genomic and predicted cDNA sequences obtained through the Genoscope Vitis genome browser (http://www.genoscope.cns.fr/ externe/GenomeBrowser/Vitis/). In cases with numerous $(>10)$ predicted orthologs, protein sequences were obtained and nested within the Arabidopsis family (CLUSTALW, BLOSUM matrix with gap open penalty of 10 , gap extension penalty of 1) producing rooted dendrograms from which predicted orthologs grouping within a particular subgroup could be determined (Figs. 1, 2, 3, Suppl. Figs. 3, 4). Then genomic and predicted cDNA sequences were obtained for these predicted orthologs as above. An identical methodology was used in incorporating the $P$. trichocarpa orthologs and producing the unrooted dendrograms.
Primer design and validation

Within a family, predicted cDNA sequences were aligned (CLUSTALW, IUB matrix with gap open penalty of 15 , gap extension penalty of 6). All compatible primer pairs were determined using the FastPCR software's unique primer design. The actual primer pair was chosen manually based on the following criteria making it most suitable for Quantitative PCR (QPCR): the product is approximately $150 \mathrm{bp}$ in length, and the most $3^{\prime}$ sequence. Primers pairs for all the genes can be found in Suppl. File 1.

Every primer pair was validated in order to confirm that they were functioning and only yielding one specific product. This was performed by traditional PCR amplification of the product from a genomic DNA template. Total genomic DNA was obtained from Vitis vinifera "Cabernet Sauvignon" using a DNeasy Plant Kit (Qiagen, Inc., http://www1.qiagen.com) following the manufacturer's protocol. Gene fragments were amplified in a $20-\mu \mathrm{L}$ volume PCR reaction containing $0.25 \mu \mathrm{M}$ of each primer, $1.5 \mathrm{mM} \mathrm{MgCl}_{2}, 0.4 \mathrm{mM}$ dNTPs, $0.4 \mathrm{U}$ of Taq polymerase and $20 \mathrm{ng}$ of template. The PCR profile was 30 cycles of $92^{\circ} \mathrm{C}$ for $30 \mathrm{~s}, 58^{\circ} \mathrm{C}$ for $30 \mathrm{~s}$, and $65^{\circ} \mathrm{C}$ for $1 \mathrm{~min}$. Gene amplicons were separated with a $2 \%$ agarose gel stained with ethidium bromide. PCR products were purified via the Qiaquick PCR Purification Kit (Qiagen, Inc., http://www1. qiagen.com) and directly sequenced to confirm their identity.

\section{Semi-quantitative PCR analyses}

In order to test the expression of all the orthologs in the grapevine berry, semi-quantitative PCR was performed on skin cDNA of control berries at three different stages of ripening, before, at and after the onset of ripening. The cDNA normalization among samples was based on the expression of the VvUbiquitin1 gene. PCR conditions were the same described above, and amplified fragments were separated with a $2 \%$ agarose gel stained with ethidium bromide.

\section{Expression profiling}

Total RNA was extracted from $0.3 \mathrm{~g}$ of berry skin following the procedure described in Iandolino et al. (2004) and treated with $0.5 \mathrm{U} / \mu \mathrm{g}$ RQ1 DNase (Promega, http:// www.promega.com). RNA was quantified using a Nanodrop ND-1000 spectrophotometer (Thermo Scientific, http://www. thermo.com). Each sample was quantified twice and the mean of the two technical replicates calculated. First strand cDNA was synthesized using $2 \mu \mathrm{g}$ of RNA, $0.5 \mu \mathrm{M}(\mathrm{dT})$ 18 primer, and $50 \mathrm{U}$ of $\mathrm{M}-\mathrm{MLV}$ reverse transcriptase (Promega, http://www.promega.com). QPCR was carried 
out in an ABI PRISM 7500 sequence detector (Applied Biosystems, http://www3.appliedbiosystems.com). Each reaction $(20 \mu \mathrm{L})$ contained $250 \mathrm{nM}$ of each primer, $5 \mu \mathrm{L}$ of 1:400 diluted cDNA, and $10 \mu \mathrm{L}$ of Power SYBR Green Master Mix (Applied Biosystems, http://www3. appliedbiosystems.com). Thermal cycling conditions were $95^{\circ} \mathrm{C}$ for $10 \mathrm{~min}$ followed by $95^{\circ} \mathrm{C}$ for $30 \mathrm{~s}, 60^{\circ} \mathrm{C}$ for $60 \mathrm{~s}$, for 40 cycles, followed by $T_{\mathrm{m}}$ determination. Each sample was run in duplicate. In addition, VvUbiquitin1 (TC32075, TIGR database) was also quantified for every sample. For the field experiment, absolute expression level of VvUbiquitin1 was determined from standard curves established from genomic DNA standards and absolute levels of expression for each gene determined (Yun et al. 2006). Gene expression is expressed as $\log _{2}$ copy number/ ng RNA. For berry culture experiments expression was not quantified absolutely due to limited total mRNA sample material, but instead expressed relative to VvUbiquitinl expression using the comparative $C_{\mathrm{T}}$ methodology. Gene expression was expressed as mean and standard error calculated across three biological replicates.

\section{Berry culture}

Cabernet Sauvignon clusters were collected from fieldgrown vines (UC Davis experimental vineyard) at 61 DAA. Clusters were surfaced sterilized for $10 \mathrm{~s}$ in a $70 \%$ ethanol solution, $10 \mathrm{~min}$ in a $1 \%$ bleach solution, and then rinsed three times with sterilized water. Berries were removed from the clusters by cutting the stem at the peduncle level, and the peduncle was removed from the rest of the fruit with a scalpel. Berries were weighed and individually cultured for 23 days in $20 \mathrm{~mL}$ glass vials filled with $7 \mathrm{~mL}$ of six different $1 \%$ agarose media $2 \%$ sucrose, $10 \%$ sucrose, $200 \mu \mathrm{M}$ ABA ([+] cis, trans-ABA, A.G. Scientific, Inc., http://www.agscientific.com) alone, $2 \%$ sucrose $200 \mu \mathrm{M}$ ABA, $10 \%$ sucrose $10 \mu \mathrm{M}$ ABA, $10 \%$ sucrose $200 \mu \mathrm{M} \mathrm{ABA}$. The 2 and $10 \%$ sucrose concentrations used in this study approximate sugar concentrations of berries prior to $\left(3-4^{\circ} \mathrm{Brix}\right)$ and at $\left(>6-7^{\circ} \mathrm{Brix}\right)$, the onset of ripening in the field (Matthews et al. 1987; Matthews and Anderson 1988). Each treatment was replicated ten times. Berry color changes were visually analyzed twice, 10 days after $T_{0}$ and at the end of the experiment. Elasticity $(E)$ was measured at $T_{0}$ and at the end of the experiment. In short, berry elasticity was determined non-destructively using a custom-fabricated instrument, which measured force and displacement during berry compression. As described in Thomas et al. (2008), the observed force/displacement relation was fit using SAS PROC NLIN (version 8.2, SAS Institute Inc., http://www.sas.com) to that expected for compression of a perfectly elastic sphere (Hertz equation, rearranged from Eq. 2 of Ravi et al. 2006). 23 days after
$T_{0}$, berries were collected from the vials, weighed, and stored at $-80^{\circ} \mathrm{C}$ till the tissues were processed for the RNA extractions.

Three berries from the $2 \%$ sucrose, $10 \%$ sucrose, $10 \%$ sucrose $10 \mu \mathrm{M} \mathrm{ABA}, 10 \%$ sucrose $200 \mu \mathrm{M}$ ABA treatments were peeled and total RNA was extracted from each individual skin following the procedure described above.

Statistical analysis

All expression data was log transformed according to Rieu and Powers (2009) prior to statistical analysis. For the field experiment, ANOVAs were carried out comparing expression across time by each treatment. For treatment effects, means at each sample date were compared by Tukey's HSD. For berry culture experiments, differences between treatments were compared by Tukey's HSD. All analyses were carried out using JMP-SAS software (SAS Institute Inc., http://www.sas.com).

\section{Results}

\section{Orthologous families}

Utilizing the sequenced grape genome (Jaillon et al. 2007), 67 genes were identified representing orthologs of sugar and ABA-related genes in 10 gene families (Figs. 1-3, Suppl. Figs. 2-4). The genomic complexity of these families varied from small families with just one or few genes (e.g. the RGS1 and GPA1 families; see Suppl. Figs. 2b, c) to large families made up of nearly 100 genes (Figs. 1-3). Small gene families were comprehensively characterized for all grape orthologs, while only those subgroups containing genes specifically shown to be involved in sugar and ABA signaling were included for large gene families. Given the scope of this work, we focused primarily on those gene families encoding the following well characterized orthologs (1) the Arabidopsis Class I HB transcription factors, (2) the Arabidopsis ABA-insensitive mutants, abil and $a b i 2$, encoding $\mathrm{PP} 2 \mathrm{C}$ protein phosphatases, and (3) the WRKY transcription factors SUSIBA2, AtWRKY4, and AtWRKY34. Other gene families are summarized and referenced as supplemental material when pertinent.

The homeodomain-leucine zipper, or homeobox (HB) transcription factors represent a medium-sized gene family with approximately 47 members in Arabidopsis. This family has been delimited into four "Classes", and 4 of the 17 members of the Class I AtHBs have been shown to be involved in ABA responses across diverse tissues (Henriksson et al. 2005). In addition, the expression of three AtHB6, 7, and 12, have been show to be up-regulated by ABA (Johannesson et al. 2003; Lee and Chun 1998; 
Fig. 1 Vitis vinifera orthologs of the Class I HB transcription factors. a Rooted dendrogram of the entire Arabidopsis HB family with nested grape orthologs. Class I, and various subgroups are colored. b Unrooted dendrogram of the Class I HBs clustering AtHB5, AtHB6, AtHB7, AtHB12 (green dots) and other Vitis vinifera (red dots), Arabidopsis, and Populus trichocarpa orthologs. NCBI and Vitis Genoscope accessions are given
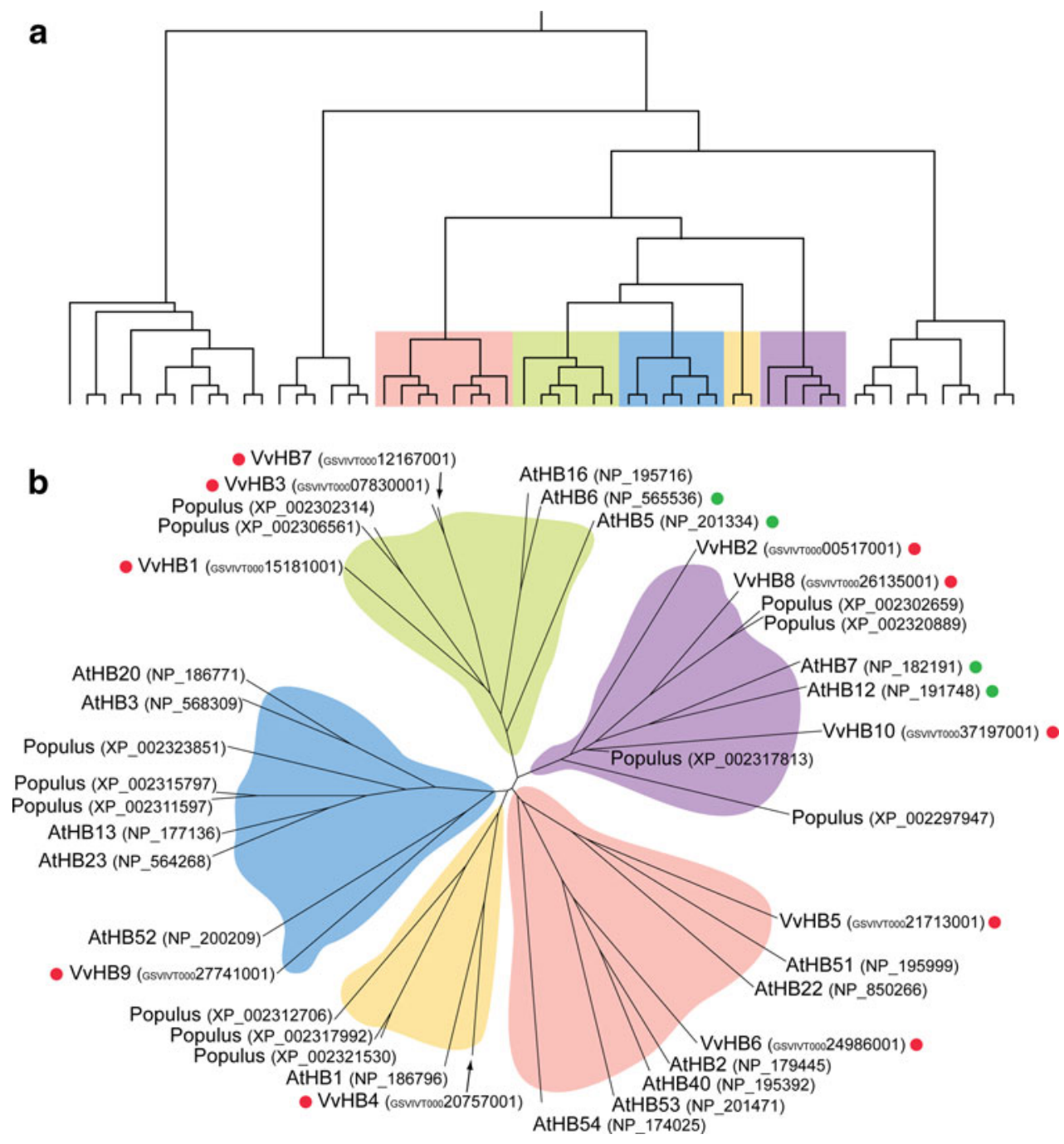

Soderman et al. 1996, 1999). An examination of the grape genome identified 10 orthologs that cluster with the Class 1 HBs (Fig. 1).

The PP2C protein phosphatases represent another large gene family being made up of 80 genes in Arabidopsis (Xue et al. 2008). Within this family group a cluster of genes (referred to as Group A) containing many genes that have been characterized to function in the ABA-signaling pathway; most notably, the ABA-insensitive mutants, abil and abi2 (Leung et al. 1994, 1997; Meyer et al. 1994). In addition, AtPP2C-A, AtHAB1, AtHAB2, and AtAHG1, also members of Group A, function in ABA signaling across diverse tissues (Kuhn et al. 2006; Nishimura et al. 2007; Rubio et al. 2009; Saez et al. 2004). In Arabidopsis, all the members of this group are induced by ABA treatment. In grape, nine VvPP2Cs clustered in group A (Fig. 2).

The WRKY transcription factors are a large gene family, consisting of approximately 70 members making up three groups in Arabidopsis (Eulgem et al. 2000; Wu et al. 2005). The barley (Hordeum vulgare) HvSUSIBA2, and
AtWRKY2, and AtWRKY34, all fall within the same group consisting of 14 members in Arabidopsis (referred to as Group I or Ia by Eulgem et al. 2000 and Wu et al. 2005, respectively). HvSUSIBA2 modulates the expression of a barley isoamylase gene during seed development via the binding of SURE (SUgar REsponsive) elements (Sun et al. 2003). In addition, Sun et al. (2003) demonstrated that expression of $H v S U S I B A 2$ is induced by exogenous sugar and its native expression profile during seed development correlates strongly with endogenous sucrose levels. Hammargren et al. (2008) found that the sugar responsiveness of a nucleoside diphosphate kinase is altered in Atwrky2 and Atwrky34 mutant backgrounds. Grape contained 13 putative orthologs that fall within this group (Fig. 3).

\section{Expression profiling}

Expression profiling was carried out in berry skins of fieldgrown Cabernet Sauvignon in order to identify those orthologs expressed during ripening. In addition, 
Fig. 2 Vitis vinifera orthologs of the ABA-related subfamily A PP2Cs. a Rooted dendrogram of the entire Arabidopsis PP2C family with nested grape orthologs. Group A, containing the ABA-insensitive mutants, abil and abi2, are colored. b Unrooted dendrogram of Group A clustering AtABI1, AtABI2, AtPP2C-A, AtHAB1, AtHAB2, and AtAHG1 (green dots) and other Vitis vinifera (red dots), Arabidopsis, and Populus trichocarpa orthologs. NCBI and Vitis Genoscope accessions are given
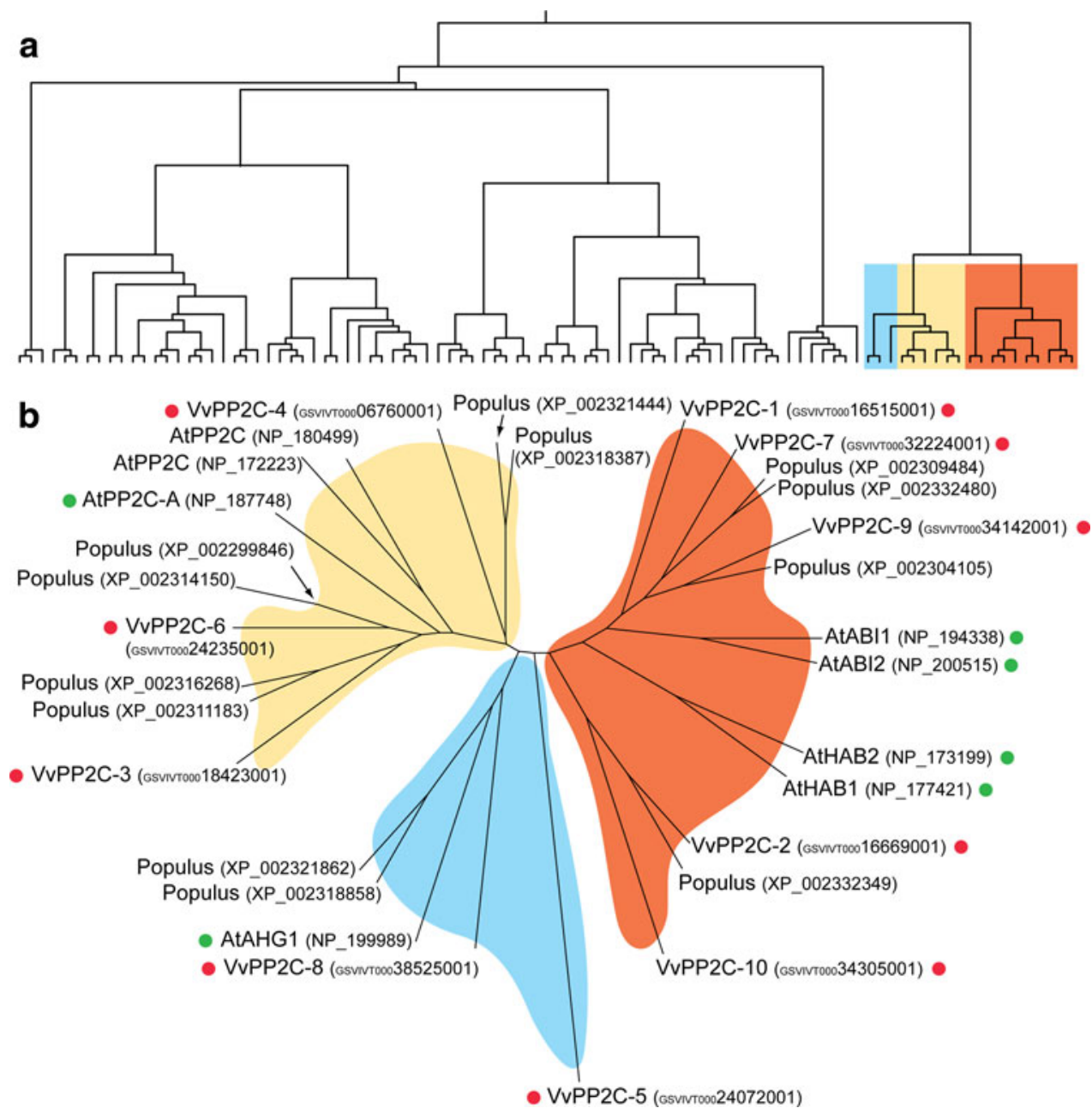

expression profiles under both control- and deficit-irrigated (denoted ED, Early water Deficit) conditions were compared in order to identify orthologs whose expression pattern reflected the advancement of ripening under ED. Water deficits were applied continuously from fruit set until to the onset of ripening, resulting in an average difference in midday leaf water potential of $0.36 \mathrm{MPa}$ before the onset of ripening and no difference during ripening (Table 1). Of the 67 orthologous genes identified, 38 (57\%) were expressed in grape berries. A summary of the expression profiles of all the genes examined in this study can be found in Figs. 4 and 5 while more detailed expression data is contained in Suppl. File 1. The majority of these genes were differentially regulated during berry development, with $26(68 \%)$ exhibiting statistically significant changes with time in control and/or ED (Figs. 4, 5). There were few statistically significant differences in the magnitude of expression between control and ED (Figs. 4, 5, Suppl. File 1). Six genes exhibited statistically significant differences between control and ED. Four of these instances, $V v H B 8, V v \operatorname{SnRK5}, V v P P 2 C-3$, and $V v P P 2 C-7$, all exhibit elevated levels of expression in ED at or just prior to the onset of ripening (See Suppl. File 1 for exact expression values).

Eight of the $V v W R K Y \mathrm{~s}$ selected for analysis were expressed in ripening grape. $V v W R K Y 3,5$, and 6 , were all differentially expressed during ripening and exhibited similar patterns of expression (Fig. 4, Suppl. File 1). They were up-regulated ranging from 4- to 16-fold at the onset of ripening. There were no significant differences in the expression of $V v W R K Y 1,2,16,18$, and 19 across development or during water deficit (Fig. 4).

Of the 10 Class I, $V v H B$ orthologs only four $(V v H B 2,3$, 4 , and 8 ) are expressed in fruit during ripening (Fig. 5, Suppl. File 1). Both $V v H B 4$ and 8 were strongly up-regulated at the onset of ripening, exhibiting increases of $>16$-fold. $V v H B 8$ is up-regulated much earlier under water deficit and high levels persist until late in ripening. $V v H B 4$ is down-regulated early in development under ED. $V v H B 2$ expression in controls generally decreased during development with a small up-regulation at the onset of ripening, although these changes were not statistically significant. Under ED, however, this pattern of expression is more pronounced with a sharp eightfold decrease in 
Fig. 3 Vitis vinifera orthologs of the sugar-related WRKY transcription factors. a Rooted dendrogram of the entire Arabidopsis WRKY family with nested grape orthologs. Group I, and various subgroups containing the sugar-related AtWRKY2 and AtWRKY34 are colored. b Unrooted dendrogram of Group I clustering HvSUSIBA2, AtWRKY2 and AtWRKY34 (green dots) and other Vitis vinifera (red dots), Arabidopsis, and Populus trichocarpa orthologs. NCBI and Vitis Genoscope accessions are given
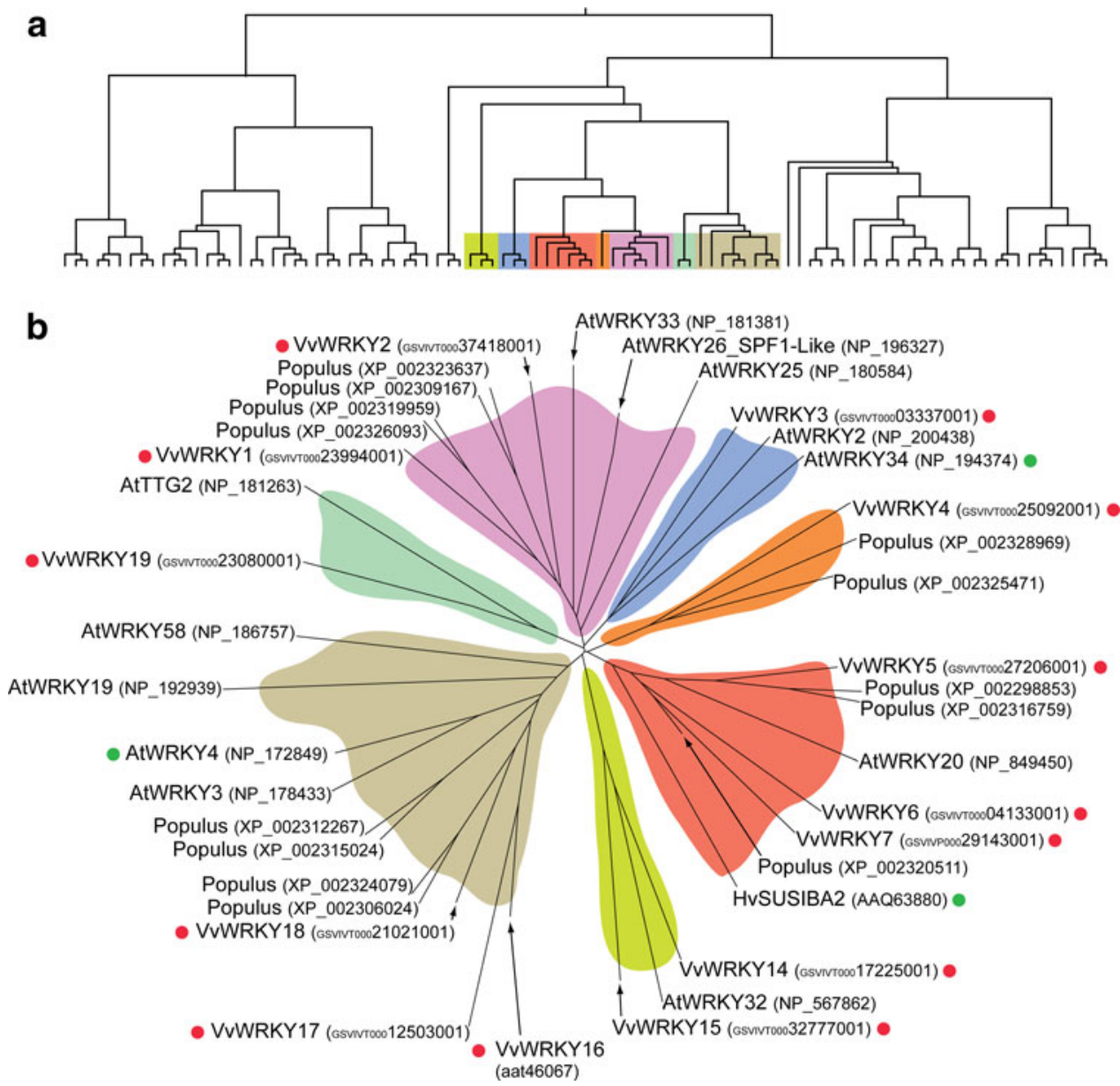

Table 1 Average midday leaf water potential $\left(\Psi_{\text {leaf }}\right)$ in control (C) and early deficit-irrigated field-grown Cabernet Sauvignon grapevines during the periods prior to and after the onset of ripening (approx. 77 DAA)

\begin{tabular}{lll}
\hline DAA & \multicolumn{2}{l}{ Average Midday $\Psi_{\text {leaf }}(\mathrm{MPa})$} \\
\cline { 2 - 3 } & Control & Early deficit \\
\hline $33-77$ & $-1.03 \pm 0.07^{\mathrm{a}}$ & $-1.39 \pm 0.05^{\mathrm{b}}$ \\
$77-133$ & $-1.11 \pm 0.08^{\mathrm{a}}$ & $-1.15 \pm 0.07^{\mathrm{a}}$
\end{tabular}

Different letters denote significant differences $(P<0.01$, Student's $t$ test)

expression at 81 DAA (Fig. 5). $V v H B 3$ was constitutively expressed during ripening with no significant changes over time or under ED.

Six of the $V v P P 2 C s$ were expressed in grape berries. $V v P P 2 C-3,6,7$, and 9 were all differentially expressed during ripening, while $V v P P 2 C-1$ and 5 expression did not change significantly (Fig. 5, Suppl. File 1). VvPP2C-3, 6, 7 , and 9 were all up-regulated strongly at the onset of ripening increasing as much as 16 -fold. $V v P P 2 C-3$ and $V v P P 2 C-7$ expression were clearly induced earlier and to higher levels in ED. Both exhibited statistically significant two to fourfold greater levels of expression in green berries at the onset of ripening.

Responses of immature berries to sugar and $\mathrm{ABA}$ in berry culture

In order to more directly test the effects of sugar and $\mathrm{ABA}$ on the onset of ripening, immature Cabernet Sauvignon berries were harvested from the field at 61 DAA $\left(T_{0}\right)$ and cultured in the presence of various combinations of sucrose and ABA until 84 DAA, a period of 23 days. The onset of ripening in the clusters from which these berries were collected in the field occurred at approximately 73 DAA, therefore the cultured berries were collected approximately 12 days prior to the onset of ripening.

Ripening phenomena were induced in berry culture when treated with sucrose and ABA as evidenced by changes in color, softening, and gene expression. Berries treated with $10 \%$ sucrose and various ABA concentrations changed color while those treated with 2 or $10 \%$ sucrose alone remained green (Fig. 6a). $200 \mu \mathrm{M} \mathrm{ABA}$ and $2 \%$ sucrose $+200 \mu \mathrm{M}$ ABA treatments were included in our 
Fig. 4 Summary of the gene families involved in sugar signaling examined in this work. Components are presented in their proposed positions in the signaling network. Gene families are 1 the putative SUT2 sucrose sensor, 2, 3 core G-protein signaling components GPA1 and RGS1, 4 hexokinases $(H x k), 6$. Snf1-related kinases (SnRK1s), 7 WRKY transcription factors. The expression patterns of each gene in both control $(C)$ and water deficit $(E D)$ are summarized across three developmental stages I prior to the onset of ripening, II at the onset of ripening, and III late in ripening (See Supplemental File 1 for more detailed data). Asterisks denote significant changes in expression with time $(P<0.05$, ANOVA), and boxes denote significant differences between treatments $(P<0.05$, Tukey's HSD). Mean level of expression in $\log _{2}$ copies/ng RNA are expressed categorically as false color according to the legend above $(n=3)$. Signaling network figure adapted from Rolland et al. (2006)
Expression ( $\log _{2}$ copies/ng RNA) $\begin{array}{llllll}0-1.9 & 2-3.9 & 4-5.9 & 6-7.9 & 8-9.9 & 10-12\end{array}$
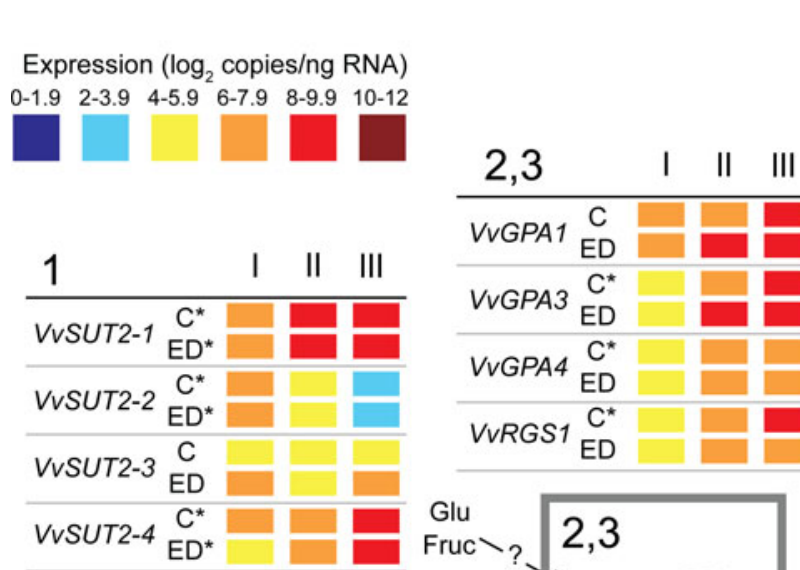

7

\begin{tabular}{|c|c|c|}
\hline $\begin{array}{lc}\text { VvWRKY1 } & \mathrm{C} \\
& \mathrm{ED}\end{array}$ & & \\
\hline VvWRKY2 $\begin{array}{c}\mathrm{C} \\
\mathrm{ED}\end{array}$ & & \\
\hline$V_{v W R K Y 3} \mathrm{C}_{\mathrm{ED}}^{\mathrm{CD}^{\star}}$ & & \\
\hline VuWRKY5 ${ }_{\mathrm{ED}}^{\mathrm{C}^{*}}$ & & \\
\hline $\begin{array}{ll}\text { VUWRKY } & \mathrm{C}^{*} \\
\mathrm{ED}\end{array}$ & 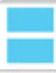 & \\
\hline$V_{v W R K Y 16} \underset{\mathrm{ED}}{\mathrm{C}}$ & & \\
\hline VvWRKY18 $\underset{\mathrm{ED}}{\mathrm{C}}$ & & \\
\hline VvWRKY19 $\underset{\mathrm{ED}}{\mathrm{C}}$ & & \\
\hline
\end{tabular}

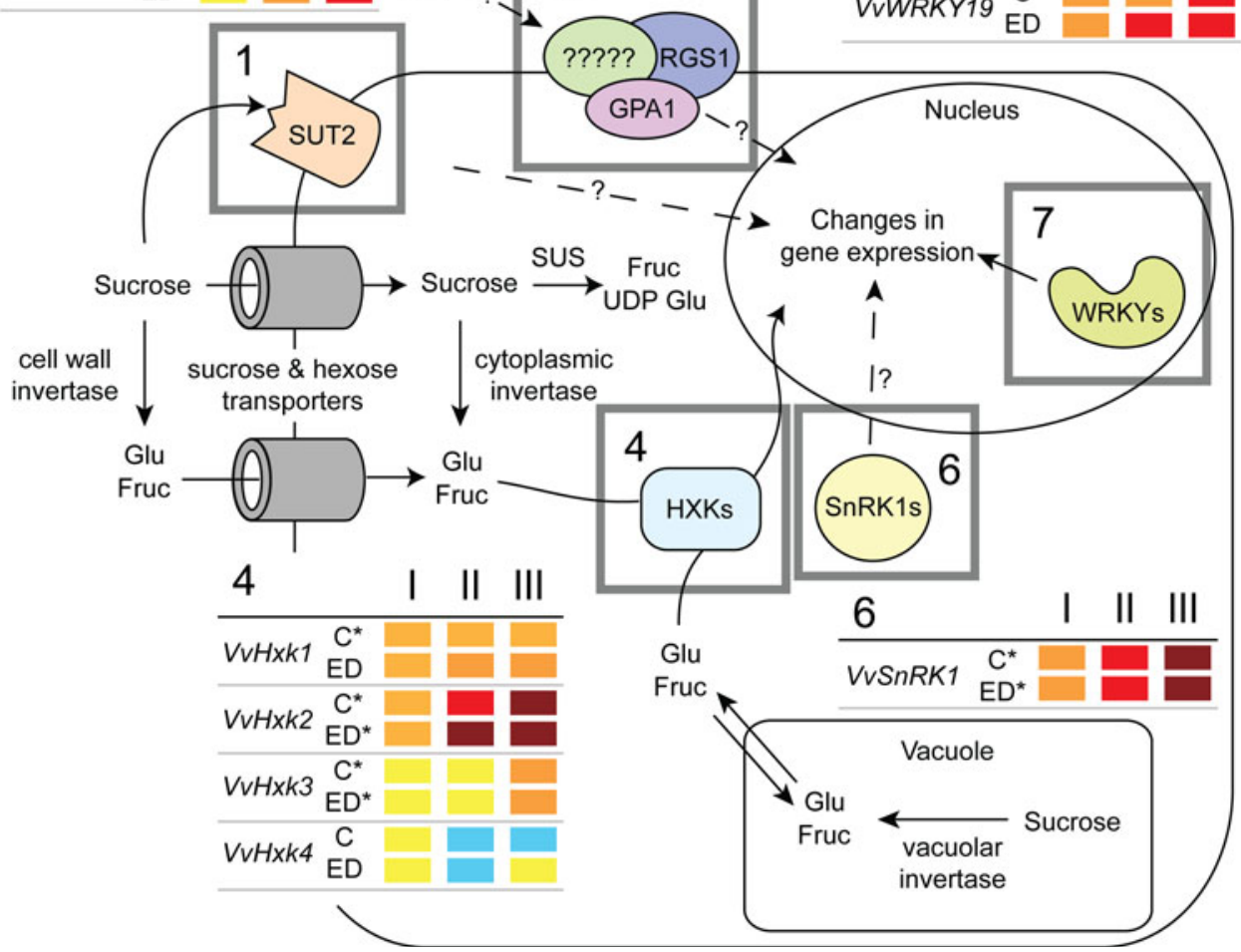

analyses but yielded no results because of a phenomenon where the berries exploded reproducibly (Suppl. Fig. 5). On average, cultured berries gained weight over the culturing period (Fig. 6a). Sucrose treatments of 2 and 10\% showed the greatest weight gains corresponding to gains of 21 and $8 \%$, respectively. Berries cultured in the presence of $10 \%$ sucrose with the addition of various ABA concentrations showed average weight gains of approximately $4 \%$. Previous studies have found that a precipitous drop in grape berry elasticity (a measure of fruit softening) occurs just prior to the onset of ripening in grape (Thomas et al. 2008; Wada et al. 2009). In our current culture experiments, berry elasticity remained equal to that at $T_{0}$ in the 2 and $10 \%$ sucrose treatments, while sharply decreasing (95\% of elasticity at $T_{0}$ ) with ABA treatment (Fig. 6b). Finally, the grape Myb transcription factor $V v M y b A l$ was utilized as a molecular marker for the onset of ripening. $V v M y b A 1$ is responsible for activating anthocyanin biosynthesis and has a distinct pattern of expression; being absent prior to the onset of ripening at which time it is strongly up-regulated (Kobayashi et al. 2002). In berry skins, $V v M y b A l$ expression was completely absent from the 2 and $10 \%$ sucrose treatments and was strongly up-regulated in the $10 \%$ sucrose $+\mathrm{ABA}$ treatments as expected (Fig. 6c).

We hypothesized that orthologs of gene families regulated by sugar and $\mathrm{ABA}$, whose expression was strongly up-regulated at the onset of ripening and advanced under $\mathrm{ED}$, would be regulated similarly by sugar and/or ABA in cultured berries. To test this, changes in the expression of $V v H B 4, V v H B 8, V v P P 2 C-3$, and $V v P P 2 C-6$ were investigated in skins of cultured berries. In the field, all genes 
Fig. 5 Summary of the gene families involved in ABA signaling examined in this work. Components are presented in their proposed positions in the signaling network. Gene families are 2, 3 core G-protein signaling components GPA1 and RGS1, 5 PP2C protein phosphatases, 6 Snf1-related kinases ( $S n R K 2 s$ and $3 \mathrm{~s}), 8$ homeobox $(H B)$ transcription factors, $9 \mathrm{ABF}$ transcription factors, $10 \mathrm{AP} 2$ transcription factors. The expression patterns of each gene in both control $(C)$ and water deficit $(E D)$ are summarized across three developmental stages I prior to the onset of ripening, II at the onset of ripening, and III late in ripening (See Supplemental File 1 for more detailed data). Asterisks denote significant changes in expression with time $(P<0.05$, ANOVA $)$, and boxes denote significant differences between treatments $(P<0.05$, Tukey's HSD). Mean level of expression in $\log _{2}$ copies/ng RNA are expressed categorically as false color according to the legend above $(n=3)$. Signaling network figure adapted from Hirayama and Shinozaki (2007)

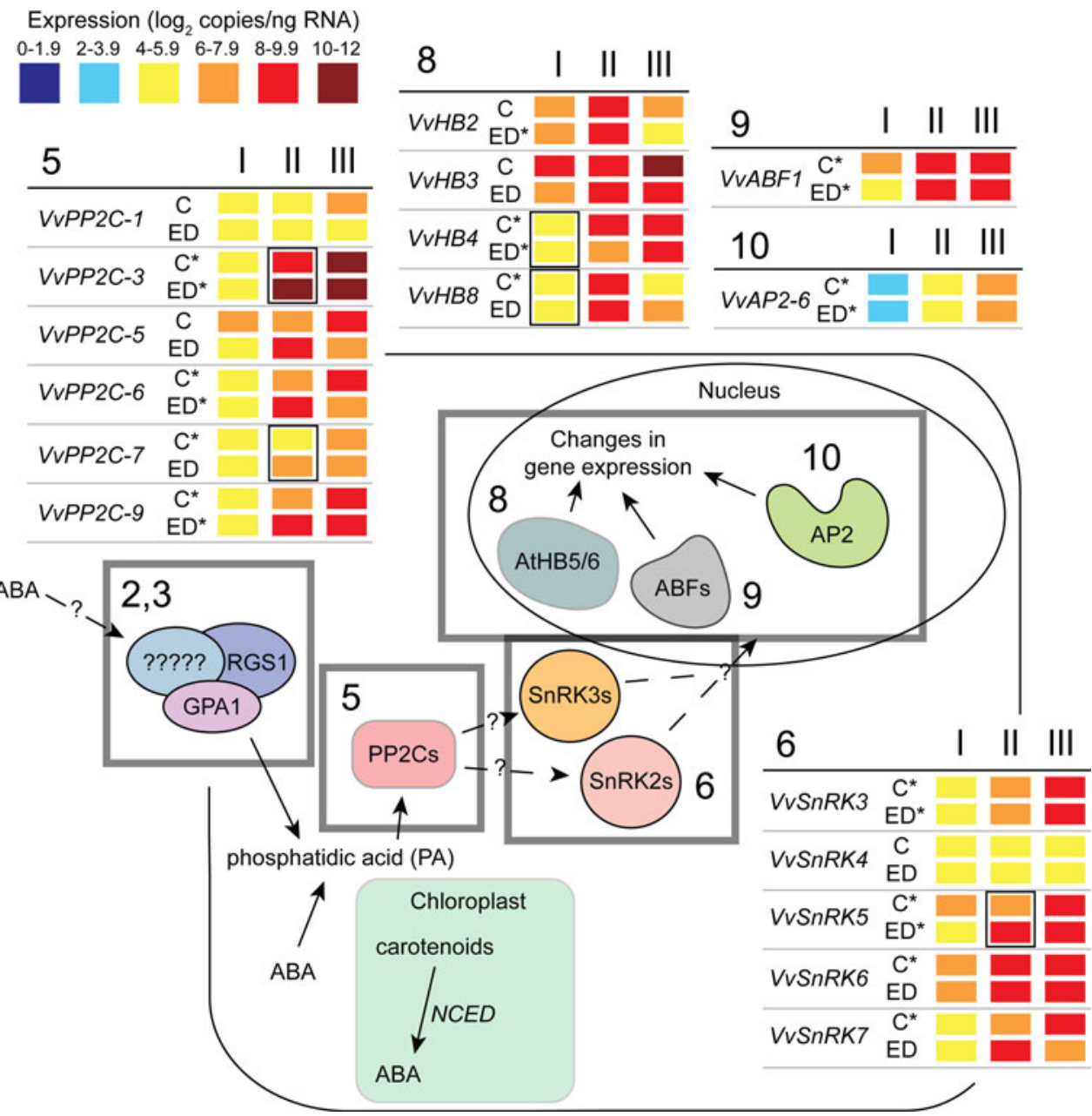

were strongly up-regulated at the onset of ripening and advanced under ED (Fig. 7, left column) and in berry culture, expression was strongly induced in the presence of $10 \%$ sucrose $+\mathrm{ABA}$ when compared with treatments of 2 and $10 \%$ sucrose alone (Fig. 7, right column). Among those genes analyzed, the magnitude of induction in the field versus in berry culture was variable. For example, when data from Fig. 7 was expressed as fold change both $V v H B 4$ and $V v P P 2 C$ - 3 were induced 10-fold from 57 to 74 DAA in the field compared to 6- and 40-fold in culture, respectively.

\section{Discussion}

The transcriptional data in this study demonstrate that numerous sugar and ABA-signaling orthologs are expressed during ripening in grape, and identify novel candidates in the control of nonclimacteric fruit ripening. Several genes exhibited patterns of expression correlating with sugar and $\mathrm{ABA}$ accumulation at the onset of ripening in field-grown fruit. Changes in color, softening, and gene expression analogous to the onset of ripening in the field were induced in berry culture when treated with sucrose and $\mathrm{ABA}$, demonstrating their role in controlling the onset of ripening. This study shows that many orthologous sugar and ABA-signaling components are regulated in fleshy fruit similar to their regulation originally characterized in model systems across diverse processes.

Sugar and ABA-signaling orthologs in fruit

These genes are easily delimited through nesting the currently available grape sequences comprising a gene family within their corresponding family in Arabidopsis. However, the current grape genome assembly, and its annotated proteome, certainly does not identify all the genes present in the grape genome so our analyses most likely failed to identify some orthologs.

In the current study, we chose to use QPCR in our expression analyses instead of the current grape microarray for several reasons. First, the majority of the genes analyzed here are not present on the current Affymetrix Vitis vinifera gene chip since the chip was derived from ESTs 

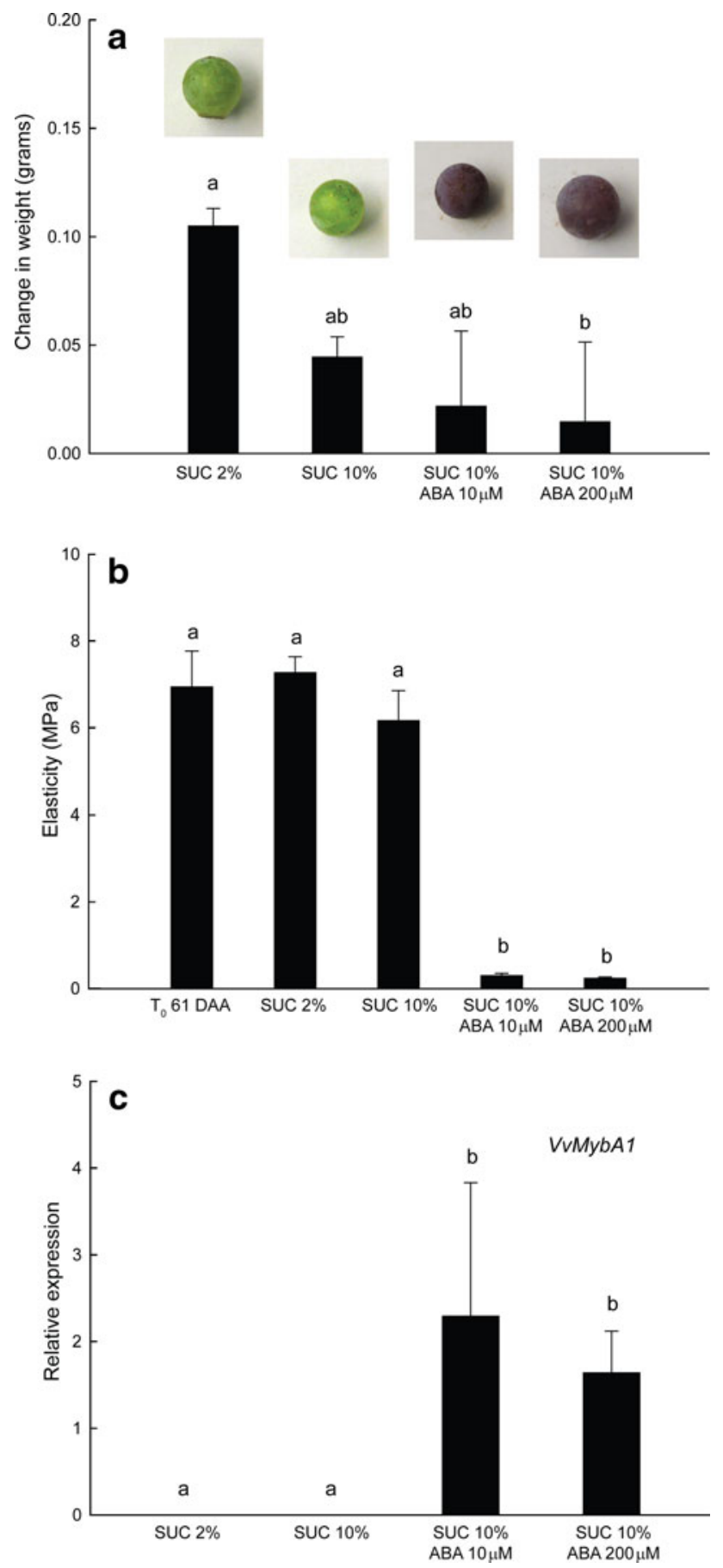

Fig. 6 Changes in immature berries cultured with various sugar and ABA treatments. a Change in berry weight over the course of treatment from $T_{0}$ (61 DAA) until 84 DAA. Photos of a representative berry from each treatment shown above. b Berry elasticity at $T_{0}$ and at the end of treatments 84 DAA. c $V v M y b A l$ gene expression at 84 DAA. Values are means with bars representing SE $(n=3)$. Different letters signify significant differences (a $P<0.05$, b, c $P<0.01$; Tukey's HSD)

and the present study utilizes the complete genome. Second, microarrays suffer from several limitations one of which is that they are particularly insensitive in quantifying low abundant transcripts (reviewed in Draghici et al. 2006). Transcription factors are a largely low abundance transcripts, and a study in Arabidopsis comparing QPCR and Affymetrix microarray approaches found that the microarray could detect $<55 \%$ of 1,400 transcription factors tested, compared to $>85 \%$ via QPCR (Czechowski et al. 2004). Furthermore, cross-hybridization is common on microarrays, which is especially problematic when considering conserved gene families like those examined here. However, those genes represented on the chip were identified and expression profiles were compared with those determined via microarray analyses in two recent studies. Notably, Koyama et al. (2009) demonstrated via microarray that a $V v H B$ transcription factor (Probeset ID 1613946_s_at; Affymetrix Vitis vinifera gene chip), identical to $V v H B 8$ in this study, is also up-regulated at the onset of ripening and in response to exogenous sugar and ABA. For several other genes, expression profiles in the current study are nearly identical to those found by Deluc et al. (2007).

Many grape orthologs of genes shown previously to be modulated by sugar and/or ABA in model systems exhibited expression patterns during ripening, and in response to water deficit, consistent with their modulation by sugar and/or ABA in grape. More specifically, these genes are induced at the onset of ripening and induced earlier, and to higher levels, under water deficit. This characteristic pattern of expression is shared with many flavonoid pathway genes (Fig. 8) (Castellarin et al. 2007a), and these correlations in expression throughout ripening suggest common regulatory mechanisms. Experiments in berry culture demonstrated that several sugar and ABA-signaling orthologs, and $V v M y b A 1$, a transcriptional activator of anthocyanin biosynthesis, are up-regulated by exogenous ABA in the presence of high sucrose. These data suggest that sugar and $\mathrm{ABA}$ play a predominant role in regulating the expression of a suite of genes at the onset of ripening, including those responsible for anthocyanin biosynthesis and components of their own signaling pathways.

These results have interesting evolutionary implications demonstrating that some orthologs are consistently regulated by sugar and $\mathrm{ABA}$ across diverse developmental processes. Land plants, in general, have undergone abundant gene duplication through their evolutionary history (Doyle et al. 2008), although there is debate on the exact nature and timing of these events across angiosperms and in grape specifically (Jaillon et al. 2007; Velasco et al. 2007). Gene duplication is considered cornerstone to providing the raw material for evolution. A duplicate gene, now no longer essential, can undergo changes in its structure and/or regulation allowing for it to take up a novel role. The results of this study show that some of the Group A PP2Cs and Class I HBs have maintained their ABA 
Fig. 7 Expression of select $V v H B$ s and $V v P P 2 C$ s in the field (left column) and in berry culture (right column). Left column field-grown berries under control (solid lines, closed circles), and deficit irrigation (dotted line, open circles). Points are colored to denote berry color. Samples collected at the onset of ripening berries were pooled according to color and points offset slightly in graph for clarity. $P$ values are given for ANOVAs of expression with DAA (by treatment) and points at which there are significant differences between treatments are noted with an asterisk $(P<0.05$; Tukey's HSD, $n=3$ ). Right column expression in berry culture under various treatments. Values are means with bars representing SE. Different letters denote significant differences $(P<0.05$; Tukey's HSD, $n=3$ )
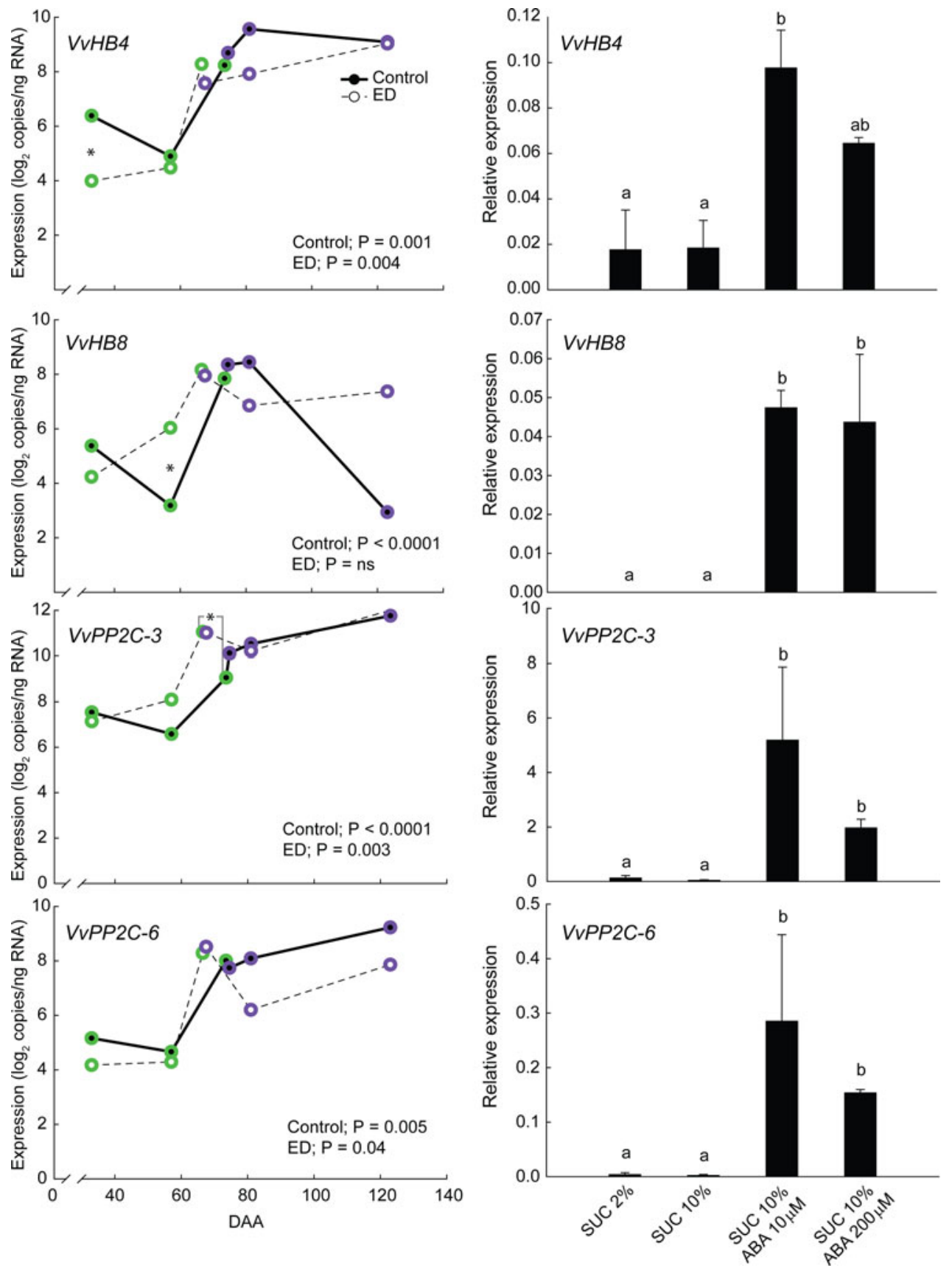

responsiveness during fruit ripening in grape. Fleshy fruit are a relatively recent evolutionary innovation (Doyle 1998; Eriksson et al. 2000). At least with regard to ABA responsiveness, the nature of regulation has been conserved, but co-opted into a completely different developmental context. This may provide for the discovery of novel cis-regulatory elements through promoter sequence comparisons across species.

In grape, advances in elucidating molecular mechanisms suffer from a lack of transgenic and related technologies on which most reverse genetic studies are based. This study demonstrates that model systems can provide fundamental knowledge and insight into function of other agronomically important plant species even in extremely divergent developmental processes. Equally, this suggests that Arabidopsis, with its wealth of tools available for facilitating reverse genetic studies, may provide a valuable system to characterize genes of interest from grape or other crop species. Already there are several examples of the successful characterization of grape genes in Arabidopsis and tobacco (Bogs et al. 2007; Hugueney et al. 2009; Poupin et al. 2007). This could prove especially useful considering the limitations of functional genetic analyses in perennial fruit crops where long propagation times are 

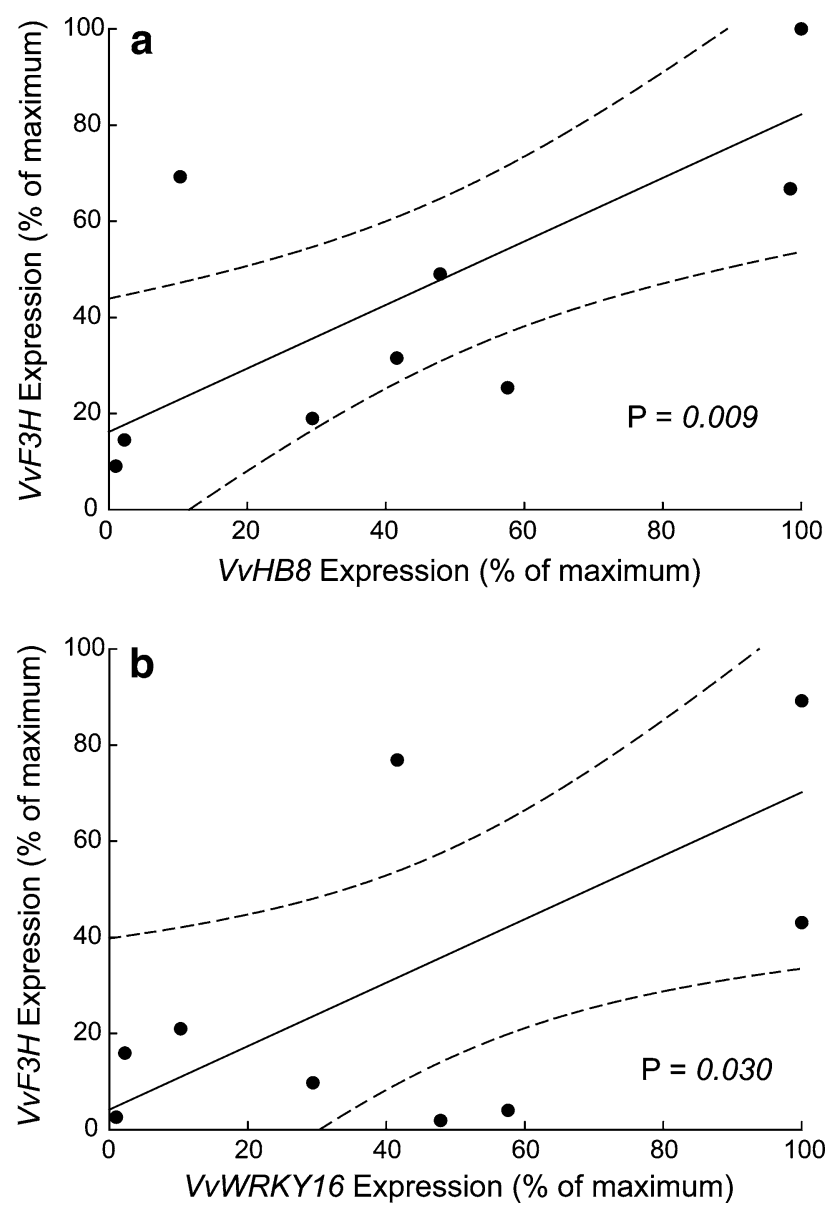

Fig. 8 Similarities in expression patterns in response to water deficit as represented by $F 3 H$, and $V v H B 8$ and $V v W R K Y 16$. Correlations between the expression of Flavanone 3-hydroxylase $(F 3 H)$ from Castellarin et al. (2007a) and a $V v H B 8$ and b $V v W R K Y 16$ from this study across all times and treatments, expressed as percent of maximum to equate scaling. Dotted lines represent $95 \%$ confidence intervals and regression $P$ values are given

prohibitive. Future studies should include attempts to complement ABA and sugar signaling mutants in Arabidopsis and other model species with their orthologs implicated in ripening.

Water deficit, $\mathrm{ABA}$, and acceleration of ripening

Changes in expression at the onset of ripening occurred earlier in ED than in controls. Previous work in our laboratory also demonstrated that ED advanced the onset of ripening, apparent from an earlier onset of color development and corresponding induction of flavonoid genes, and accelerated accumulation of anthocyanins and sugars after the onset of ripening (Castellarin et al. 2007a). Other studies examining the effects of water deficit have not found a temporal advancement in the onset of ripening, but did find that water deficits accelerated anthocyanin accumulation after the onset of ripening (Castellarin et al. 2007b; Deluc et al. 2009). That some studies have not found a temporal advancement in the onset of ripening may reflect differences in the nature of the applied water deficits. ED fruit in the current study was subject to water deficit for more than a month prior to the onset of ripening, while fruit in Castellarin et al. (2007b) and Deluc et al. (2009) was subject to water deficit for only 1-2 weeks prior to the onset of ripening. Alternatively, the weekly sampling interval used in Castellarin et al. (2007b) and Deluc et al. (2009) may have missed the acceleration as the onset of ripening occurs over $\sim 7$ days. Regardless, these studies show that differences in fruit composition brought about by water deficit are established in a very short period of time surrounding the onset of ripening whether through advancement in the onset of ripening, accelerated accumulation, or both.

At this time, there is no direct evidence demonstrating that changes in ripening brought about by water deficit are indeed mediated by ABA. However, several studies demonstrate a strong correlation between the timing of the onset of ripening and ABA. In this study, berry culture treatments demonstrate that $\mathrm{ABA}$, in the presence of high sugar, can bring about many of the changes associated with onset of ripening in grape. Wheeler et al. (2009) brought about an advancement in the onset of ripening through the repeated application of ABA to immature field-grown Cabernet Sauvignon, and Deluc et al. (2009) demonstrated that the acceleration in ripening in response to water deficit was correlated with increases in ABA. Without more sophisticated genetic studies, the evidence for ABA's role in mediating the effects of water deficit on fruit development remains corollary.

Berry culture and onset of ripening

Several lines of evidence suggest that changes in berries cultured with exogenous sucrose and ABA parallel changes in field-grown fruit at the onset of ripening. Softening, color development, and changes in gene expression (e.g. $V v M y b A 1)$ associated with onset of ripening in were brought about by culture on high sucrose $(10 \%)+$ ABA, but not with low or high sucrose treatments alone. The 2 and $10 \%$ sucrose concentrations used in this study approximate sugar concentrations of berries prior to $\left(3-4^{\circ}\right.$ Brix $)$ and at $\left(>6-7^{\circ}\right.$ Brix), the onset of ripening in the field (Matthews et al. 1987; Matthews and Anderson 1988). ABA concentrations in the culture media match $(10 \mu \mathrm{M})$ or exceed $(200 \mu \mathrm{M})$ peak ABA concentrations (approximately 4-6 $\mu \mathrm{M}$ ) at the onset of ripening in the field (Owen et al. 2009; Wheeler et al. 2009). The induction of color development in the high sucrose $+\mathrm{ABA}$ treatments was not surprising given the strong evidence for sugar and $\mathrm{ABA}$ induction of 
anthocyanin biosynthesis both in model systems (Loreti et al. 2008; Solfanelli et al. 2006) and in grape cell culture (Hiratsuka et al. 2001; Larronde et al. 1998; Matsushima et al. 1989; Pirie and Mullins 1976). Cultured berries grew and increased Brix at a rate similar to field-grown berries for the range of Brix represented by $2-10 \%$ sucrose. Similarly, the elasticity of both field-grown and cultured berries decreased from approximately 6 to $1 \mathrm{MPa}$ or less from 61 to 84 DAA (Wada et al. 2009). The parallels in patterns of gene expression are striking. Those genes strongly up-regulated at the onset of ripening in control and ED field-grown fruit were similarly regulated between high sucrose, and high sucrose + ABA treatments (Fig. 7 and Suppl. Fig. 6). Other genes, such as VvSUT2-1 were up-regulated at the onset of ripening in the field, while in culture they were up-regulated in response to sugar only (data not shown). Furthermore, other genes constitutively expressed during ripening in field experiments exhibit the same pattern of expression in culture (data not shown). Koyama et al. (2009) also demonstrated that, in culture, exogenous $\mathrm{ABA}$ brings about changes in gene expression analogous to the onset in ripening in the field.

Decrease in elasticity in response to exogenous ABA suggests that ABA treatment resulted in decreases in mesocarp cell turgor, although turgor was not measured directly in this study. Berry elasticity is tightly correlated with mesocarp cell turgor (Thomas et al. 2008). The decrease in elasticity in culture is attributable to a decrease in the $\Delta \Psi_{\mathrm{s}}$ between the symplast and apoplast (Wada et al. $2008,2009)$, and/or a decrease in cell wall rigidity through loosening of the cell wall, and not to desiccation because the berries grew during culture. In fruit, there is evidence that ABA plays a role in both of these processes through the stimulation of various invertases (Koyama et al. 2009; Pan et al. 2005; Pan et al. 2006) and cell wall-modifying enzymes (Koyama et al. 2009; Lohani et al. 2004; Parikh et al. 1990). The large weight gain, swelling of the mesocarp tissue, and berry cracking in low sucrose $+\mathrm{ABA}$ treatments, supports a role for $\mathrm{ABA}$ in stimulating cell wall loosening. This could be an interesting focus of future study.

In the introduction, we discussed the idea that components of regulatory networks can be conserved across disparate developmental processes that share commonalities. Sugar and ABA signals act across diverse processes (seed dormancy and germination, cessation of growth, stomatal control, the onset of ripening). Assuming that sugar and ABA signals work to control similar physiological processes in these different contexts what common physiology underlies their action? One strong candidate is the control of turgor, which is intimately connected to germination (Bradford 1990; Welbaum et al. 1990), stomatal control, the onset of ripening (Thomas et al. 2006; Wada et al. 2008, 2009), and the control of growth.

Acknowledgments The authors thank R.H. Phillips for cooperation and access to vineyard, Mark Krasnow for his field assistance, Hiroshi Wada for guidance in developing the berry culture, and Greg Giguere for water management. This work was funded by USDA-ARS CRIS \#5306-21220-004-00, USDA-CREES \#2005-3442-15841, and by Viticulture Consortium Grant \#06-34360-17156.

Open Access This article is distributed under the terms of the Creative Commons Attribution Noncommercial License which permits any noncommercial use, distribution, and reproduction in any medium, provided the original author(s) and source are credited.

\section{References}

Antolin MC, Santesteban H, Maria ES, Aguirreolea J, Sanchez-Diaz M (2008) Involvement of abscisic acid and polyamines in berry ripening of Vitis vinifera (L.) subjected to water deficit irrigation. Aust J Grape Wine Res 14:123-133

Bogs J, Jaffe FW, Takos AM, Walker AR, Robinson SP (2007) The grapevine transcription factor VvMYBPA1 regulates proanthocyanidin synthesis during fruit development. Plant Physiol 143:1347-1361

Bohlenius H, Huang T, Charbonnel-Campaa L, Brunner AM, Jansson S, Strauss SH, Nilsson O (2006) CO/FT regulatory module controls timing of flowering and seasonal growth cessation in trees. Science 312:1040-1043

Bradford KJ (1990) A water relations analysis of seed-germination rates. Plant Physiol 94:840-849

Cakir B, Agasse A, Gaillard C, Saumonneau A, Delrot S, Atanassova R (2003) A grape ASR protein involved in sugar and abscisic acid signaling. Plant Cell 15:2165-2180

Castellarin SD, Matthews MA, Di Gaspero G, Gambetta GA (2007a) Water deficits accelerate ripening and induce changes in gene expression regulating flavonoid biosynthesis in grape berries. Planta 227:101-112

Castellarin SD, Pfeiffer A, Sivilotti P, Degan M, Peterlunger E, Di Gaspero G (2007b) Transcriptional regulation of anthocyanin biosynthesis in ripening fruits of grapevine under seasonal water deficit. Plant Cell Environ 30:1381-1399

Chernys JT, Zeevaart JA (2000) Characterization of the 9-cisepoxycarotenoid dioxygenase gene family and the regulation of abscisic acid biosynthesis in avocado. Plant Physiol 124:343-353

Chervin C, El-Kereamy A, Roustan JP, Latche A, Lamon J, Bouzayen M (2004) Ethylene seems required for the berry development and ripening in grape, a non-climacteric fruit. Plant Sci 167:1301-1305

Conde C, Agasse A, Glissant D, Tavares R, Geros H, Delrot S (2006) Pathways of glucose regulation of monosaccharide transport in grape cells. Plant Physiol 141:1563-1577

Czechowski T, Bari RP, Stitt M, Scheible WR, Udvardi MK (2004) Real-time RT-PCR profiling of over 1400 Arabidopsis transcription factors: unprecedented sensitivity reveals novel rootand shoot-specific genes. Plant J 38:366-379

Davies C, Boss PK, Robinson SP (1997) Treatment of grape berries, a nonclimacteric fruit with a synthetic auxin, retards ripening and alters the expression of developmentally regulated genes. Plant Physiol 115:1155-1161 
Deluc LG, Grimplet J, Wheatley MD, Tillett RL, Quilici DR, Osborne C, Schooley DA, Schlauch KA, Cushman JC, Cramer GR (2007) Transcriptomic and metabolite analyses of Cabernet Sauvignon grape berry development. BMC Genomics 8:429

Deluc LG, Quilici DR, Decendit A, Grimplet J, Wheatley MD, Schlauch KA, Merillon JM, Cushman JC, Cramer GR (2009) Water deficit alters differentially metabolic pathways affecting important flavor and quality traits in grape berries of Cabernet Sauvignon and Chardonnay. BMC Genomics 10:212

Doyle JA (1998) Phylogeny of vascular plants. Annu Rev Ecol Syst 29:567-599

Doyle JJ, Flagel LE, Paterson AH, Rapp RA, Soltis DE, Soltis PS, Wendel JF (2008) Evolutionary genetics of genome merger and doubling in plants. Annu Rev Genet 42:443-461

Draghici S, Khatri P, Eklund AC, Szallasi Z (2006) Reliability and reproducibility issues in DNA microarray measurements. Trends Genet 22:101-109

Eriksson O, Friis EM, Lofgren P (2000) Seed size, fruit size, and dispersal systems in angiosperms from the early cretaceous to the late tertiary. Am Nat 156:47-58

Eulgem T, Rushton PJ, Robatzek S, Somssich IE (2000) The WRKY superfamily of plant transcription factors. Trends Plant Sci 5:199-206

Fu FQ, Mao WH, Shi K, Zhou YH, Asami T, Yu JQ (2008) A role of brassinosteroids in early fruit development in cucumber. J Exp Bot 59:2299-2308

Gibson SI (2004) Sugar and phytohormone response pathways: navigating a signalling network. J Exp Bot 55:253-264

Giovannoni JJ (2004) Genetic regulation of fruit development and ripening. Plant Cell 16(Suppl):S170-S180

Hammargren J, Rosenquist S, Jansson C, Knorpp C (2008) A novel connection between nucleotide and carbohydrate metabolism in mitochondria: sugar regulation of the Arabidopsis nucleoside diphosphate kinase 3a gene. Plant Cell Rep 27:529-534

Henriksson E, Olsson ASB, Johannesson H, Johansson H, Hanson J, Engstrom P, Soderman E (2005) Homeodomain leucine zipper class I genes in Arabidopsis. Expression patterns and phylogenetic relationships. Plant Physiol 139:509-518

Hiratsuka S, Onodera H, Kawai Y, Kubo T, Itoh H, Wada R (2001) ABA and sugar effects on anthocyanin formation in grape berry cultured in vitro. Sci Hortic 90:121-130

Hirayama T, Shinozaki K (2007) Perception and transduction of abscisic acid signals: keys to the function of the versatile plant hormone ABA. Trends Plant Sci 12:343-351

Hugueney P, Provenzano S, Verries C, Ferrandino A, Meudec E, Batelli G, Merdinoglu D, Cheynier V, Schubert A, Ageorges A (2009) A novel cation-dependent o-methyltransferase involved in anthocyanin methylation in grapevine. Plant Physiol 150:2057-2070

Iandolino AB, da Silva FG, Lim H, Choi H, Williams LE, Cook DR (2004) High-quality RNA, cDNA, and derived EST libraries from grapevine (Vitis vinifera L.). Plant Mol Biol Rep 22:269278

Imaizumi T, Kay SA (2006) Photoperiodic control of flowering: not only by coincidence. Trends Plant Sci 11:550-558

Jaillon O, Aury JM, Noel B, Policriti A, Clepet C, Casagrande A, Choisne N, Aubourg S, Vitulo N, Jubin C, Vezzi A, Legeai F, Hugueney P, Dasilva C, Horner D, Mica E, Jublot D, Poulain J, Bruyere C, Billault A, Segurens B, Gouyvenoux M, Ugarte E, Cattonaro F, Anthouard V, Vico V, Del Fabbro C, Alaux M, Di Gaspero G, Dumas V, Felice N, Paillard S, Juman I, Moroldo M, Scalabrin S, Canaguier A, Le Clainche I, Malacrida G, Durand E, Pesole G, Laucou V, Chatelet P, Merdinoglu D, Delledonne M, Pezzotti M, Lecharny A, Scarpelli C, Artiguenave F, Pe ME, Valle G, Morgante M, Caboche M, Adam-Blondon AF, Weissenbach J, Quetier F, Wincker P, Public F-I (2007) The grapevine genome sequence suggests ancestral hexaploidization in major angiosperm phyla. Nature 449:U463-U465

Johannesson H, Wang Y, Hanson J, Engstrom P (2003) The Arabidopsis thaliana homeobox gene ATHB5 is a potential regulator of abscisic acid responsiveness in developing seedlings. Plant Mol Biol 51:719-729

Kobayashi S, Ishimaru M, Hiraoka K, Honda C (2002) Myb-related genes of the Kyoho grape (Vitis labruscana) regulate anthocyanin biosynthesis. Planta 215:924-933

Koch K (2004) Sucrose metabolism: regulatory mechanisms and pivotal roles in sugar sensing and plant development. Curr Opin Plant Biol 7:235-246

Koyama K, Sadamatsu K, Goto-Yamamoto N (2009) Abscisic acid stimulated ripening and gene expression in berry skins of the Cabernet Sauvignon grape. Funct Integr Genomics (PMID: 19841954)

Kuhn JM, Boisson-Dernier A, Dizon MB, Maktabi MH, Schroeder JI (2006) The protein phosphatase AtPP2CA negatively regulates abscisic acid signal transduction in Arabidopsis, and effects of abh1 on AtPP2CA mRNA. Plant Physiol 140:127-139

Larronde F, Krisa S, Decendit A, Cheze C, Merillon JM (1998) Regulation of polyphenol production in Vitis vinifera cell suspension cultures by sugars. Plant Cell Rep 17:946-950

Leclercq J, Adams-Phillips LC, Zegzouti H, Jones B, Latche A, Giovannoni JJ, Pech JC, Bouzayen M (2002) LeCTR1, a tomato CTR1-like gene, demonstrates ethylene signaling ability in Arabidopsis and novel expression patterns in tomato. Plant Physiol 130:1132-1142

Lee YH, Chun JY (1998) A new homeodomain-leucine zipper gene from Arabidopsis thaliana induced by water stress and abscisic acid treatment. Plant Mol Biol 37:377-384

Leung J, Giraudat J (1998) Abscisic acid signal transduction. Annu Rev Plant Physiol Plant Mol Biol 49:199-222

Leung J, Bouvier-Durand M, Morris PC, Guerrier D, Chefdor F, Giraudat J (1994) Arabidopsis ABA response gene ABI1: features of a calcium-modulated protein phosphatase. Science 264:1448-1452

Leung J, Merlot S, Giraudat J (1997) The Arabidopsis ABSCISIC ACID-INSENSITIVE2 (ABI2) and ABI1 genes encode homologous protein phosphatases $2 \mathrm{C}$ involved in abscisic acid signal transduction. Plant Cell 9:759-771

Lieberman M, Baker JE, Sloger M (1977) Influence of plant hormones on ethylene production in apple, tomato, and avocado slices during maturation and senescence. Plant Physiol 60:214-217

Lisso J, Altmann T, Mussig C (2006) Metabolic changes in fruits of the tomato dx mutant. Phytochemistry 67:2232-2238

Lohani S, Trivedi PK, Nath P (2004) Changes in activities of cell wall hydrolases during ethylene-induced ripening in banana: effect of 1-MCP, ABA and IAA. Postharvest Biol Technol 31:119-126

Loreti E, Povero G, Novi G, Solfanelli C, Alpi A, Perata P (2008) Gibberellins, jasmonate and abscisic acid modulate the sucroseinduced expression of anthocyanin biosynthetic genes in Arabidopsis. New Phytol 179:1004-1016

Lund ST, Peng FY, Nayar T, Reid KE, Schlosser J (2008) Gene expression analyses in individual grape (Vitis vinifera L.) berries during ripening initiation reveal that pigmentation intensity is a valid indicator of developmental staging within the cluster. Plant Mol Biol 68:301-315

Matsushima J, Hiratsuka S, Taniguchi N, Wada R, Suzaki N (1989) Anthocyanin accumulation and sugar content in the skin of grape cultivar Olympia treated with ABA. J Jpn Soc Hortic Sci 58:551-555

Matthews MA, Anderson MM (1988) Fruit ripening in Vitis vinifera $\mathrm{L}-$ responses to seasonal water deficits. Am J Enol Vitic 39:313-320 
Matthews MA, Anderson MM, Schultz HR (1987) Phenologic and growth responses to early and late season water deficits in Cabernet franc. Vitis 26:147-160

Mei Z, Ping L, Guanglian Z, Xiangxin L (2009) Cloning and functional analysis of 9-cis-epoxycarotenoid dioxygenase (NCED) genes encoding a key enzyme during abscisic acid biosynthesis from peach and grape fruits. J Plant Physiol 166(12):1241-1252

Meyer K, Leube MP, Grill E (1994) A protein phosphatase 2C involved in ABA signal transduction in Arabidopsis thaliana. Science 264:1452-1455

Nishimura N, Yoshida T, Kitahata N, Asami T, Shinozaki K, Hirayama T (2007) ABA-Hypersensitive Germination1 encodes a protein phosphatase $2 \mathrm{C}$, an essential component of abscisic acid signaling in Arabidopsis seed. Plant J 50:935-949

Okamoto G, Kuwamura T, Hirano K (2004) Effects of water deficit stress on leaf and berry ABA and berry ripening in Chardonnay grapevines (Vitis vinifera). Vitis 43:15-17

Owen SJ, Lafond MD, Bowen P, Bogdanoff C, Usher K, Abrams SR (2009) Profiles of abscisic acid and its catabolites in developing merlot grape (Vitis vinifera) berries. Am J Enol Vitic 60:277284

Pan QH, Li MJ, Peng CC, Zhang N, Zou X, Zou KQ, Wang XL, Yu XC, Wang XF, Zhang DP (2005) Abscisic acid activates acid invertases in developing grape berry. Physiol Plant 125:157-170

Pan QH, Yu XC, Zhang N, Zou X, Peng CC, Wang XL, Zou KQ, Zhang DP (2006) Activity, but not expression, of soluble and cell wall-bound acid invertases is induced by abscisic acid in developing apple fruit. J Integr Plant Biol 48:536-549

Parikh HR, Nair GM, Modi VV (1990) Some structural-changes during ripening of mangoes (Mangifera indica Var Alphonso) by abscisic-acid treatment. Ann Bot 65:121-127

Peppi MC, Fidelibus M, Dokoozlian N, Walker MA (2006) Abscisic acid applications improve the color of crimson seedless table grapes. Am J Enol Vitic 57:388A

Peppi MC, Walker MA, Fidelibus MW (2008) Application of abscisic acid rapidly upregulated UFGT gene expression and improved color of grape berries. Vitis 47:11-14

Pirie A, Mullins MG (1976) Changes in anthocyanin and phenolics content of grapevine leaf and fruit tissues treated with sucrose, nitrate, and abscisic acid. Plant Physiol 58:468-472

Poupin MJ, Federici F, Medina C, Matus JT, Timmermann T, ArceJohnson P (2007) Isolation of the three grape sub-lineages of Bclass MADS-box TM6, PISTILLATA and APETALA3 genes which are differentially expressed during flower and fruit development. Gene 404:10-24

Ravi N, Wan KT, Swindle K, Hamilton PD, Duan G (2006) Development of techniques to compare mechanical properties of reversible hydrogels with spherical, square columnar and ocular lens geometry. Polymer 47:4203-4209

Rieu I, Powers SJ (2009) Real-time quantitative RT-PCR: design, calculations, and statistics. Plant Cell 21:1031-1033

Rolland F, Baena-Gonzalez E, Sheen J (2006) Sugar sensing and signaling in plants: conserved and novel mechanisms. Annu Rev Plant Biol 57:675-709

Rook F, Hadingham SA, Li Y, Bevan MW (2006) Sugar and ABA response pathways and the control of gene expression. Plant Cell Environ 29:426-434

Rubio S, Rodrigues A, Saez A, Dizon MB, Galle A, Kim TH, Santiago J, Flexas J, Schroeder JI, Rodriguez PL (2009) Triple loss of function of protein phosphatases type $2 \mathrm{C}$ leads to partial constitutive response to endogenous abscisic acid. Plant Physiol 150:1345-1355

Saez A, Apostolova N, Gonzalez-Guzman M, Gonzalez-Garcia MP, Nicolas C, Lorenzo O, Rodriguez PL (2004) Gain-of-function and loss-of-function phenotypes of the protein phosphatase $2 \mathrm{C}$
HAB1 reveal its role as a negative regulator of abscisic acid signalling. Plant J 37:354-369

Soderman E, Mattsson J, Engstrom P (1996) The Arabidopsis homeobox gene ATHB-7 is induced by water deficit and by abscisic acid. Plant J 10:375-381

Soderman E, Hjellstrom M, Fahleson J, Engstrom P (1999) The HDZip gene ATHB6 in Arabidopsis is expressed in developing leaves, roots and carpels and up-regulated by water deficit conditions. Plant Mol Biol 40:1073-1083

Solfanelli C, Poggi A, Loreti E, Alpi A, Perata P (2006) Sucrosespecific induction of the anthocyanin biosynthetic pathway in Arabidopsis. Plant Physiol 140:637-646

Sun CX, Palmqvist S, Olsson H, Boren M, Ahlandsberg S, Jansson C (2003) A novel WRKY transcription factor, SUSIBA2, participates in sugar signaling in barley by binding to the sugar-responsive elements of the iso1 promoter. Plant Cell 15:2076-2092

Symons GM, Davies C, Shavrukov Y, Dry IB, Reid JB, Thomas MR (2006) Grapes on steroids. Brassinosteroids are involved in grape berry ripening. Plant Physiol 140:150-158

Telef N, Stammitti-Bert L, Mortain-Bertrand A, Maucourt M, Carde JP, Rolin D, Gallusci P (2006) Sucrose deficiency delays lycopene accumulation in tomato fruit pericarp discs. Plant Mol Biol 62:453-469

Thomas TR, Matthews MA, Shackel KA (2006) Direct in situ measurement of cell turgor in grape (Vitis vinifera L.) berries during development and in response to plant water deficits. Plant Cell Environ 29:993-1001

Thomas TR, Shackel KA, Matthews MA (2008) Mesocarp cell turgor in Vitis vinifera L. berries throughout development and its relation to firmness, growth, and the onset of ripening. Planta 228:1067-1076

Trainotti L, Pavanello A, Casadoro G (2005) Different ethylene receptors show an increased expression during the ripening of strawberries: does such an increment imply a role for ethylene in the ripening of these non-climacteric fruits? J Exp Bot 56:20372046

Trainotti L, Tadiello A, Casadoro G (2007) The involvement of auxin in the ripening of climacteric fruits comes of age: the hormone plays a role of its own and has an intense interplay with ethylene in ripening peaches. J Exp Bot 58:3299-3308

Velasco R, Zharkikh A, Troggio M, Cartwright DA, Cestaro A, Pruss D, Pindo M, Fitzgerald LM, Vezzulli S, Reid J, Malacarne G, Iliev D, Coppola G, Wardell B, Micheletti D, Macalma T, Facci M, Mitchell JT, Perazzolli M, Eldredge G, Gatto P, Oyzerski R, Moretto M, Gutin N, Stefanini M, Chen Y, Segala C, Davenport C, Dematte L, Mraz A, Battilana J, Stormo K, Costa F, Tao Q, Si-Ammour A, Harkins T, Lackey A, Perbost C, Taillon B, Stella A, Solovyev V, Fawcett JA, Sterck L, Vandepoele K, Grando SM, Toppo S, Moser C, Lanchbury J, Bogden R, Skolnick M, Sgaramella V, Bhatnagar SK, Fontana P, Gutin A, Van de Peer Y, Salamini F, Viola R (2007) A high quality draft consensus sequence of the genome of a heterozygous grapevine variety. PLoS One 2:e1326

Vitrac X, Larronde F, Krisa S, Decendit A, Deffieux G, Merillon JM (2000) Sugar sensing and Ca2+-calmodulin requirement in Vitis vinifera cells producing anthocyanins. Phytochemistry 53:659665

Wada H, Shackel KA, Matthews MA (2008) Fruit ripening in Vitis vinifera: apoplastic solute accumulation accounts for pre-veraison turgor loss in berries. Planta 227:1351-1361

Wada H, Matthews MA, Shackel KA (2009) Seasonal pattern of apoplastic solute accumulation and loss of cell turgor during ripening of Vitis vinifera fruit under field conditions. J Exp Bot 60:1773-1781

Welbaum GE, Tissaoui T, Bradford KJ (1990) Water relations of seed development and germination in muskmelon (Cucumis melo L.). 
3. Sensitivity of germination to water potential and abscisic-acid during development. Plant Physiol 92:1029-1037

Wheeler S, Loveys B, Ford C, Davies C (2009) The relationship between the expression of abscisic acid biosynthesis genes, accumulation of abscisic acid and the promotion of Vitis vinifera L. berry ripening by abscisic acid. Aust J Grape Wine Res 15:195-204

Wu KL, Guo ZJ, Wang HH, Li J (2005) The WRKY family of transcription factors in rice and Arabidopsis and their origins. DNA Res 12:9-26

Xue T, Wang D, Zhang S, Ehlting J, Ni F, Jakab S, Zheng C, Zhong Y (2008) Genome-wide and expression analysis of protein phosphatase $2 \mathrm{C}$ in rice and Arabidopsis. BMC Genomics 9:550
Yu XC, Li MJ, Gao GF, Feng HZ, Geng XQ, Peng CC, Zhu SY, Wang XJ, Shen YY, Zhang DP (2006) Abscisic acid stimulates a calcium-dependent protein kinase in grape berry. Plant Physiol 140:558-579

Yun JJ, Heisler LE, Hwang II, Wilkins O, Lau SK, Hyrcza M, Jayabalasingham B, Jin J, McLaurin J, Tsao MS, Der SD (2006) Genomic DNA functions as a universal external standard in quantitative real-time PCR. Nucleic Acids Res 34:e85 